\title{
Analysis of Landscape Design Teaching Content Based on Application Talents Training Objectives
}

\author{
Zhang Bo \\ Nanyang Institute of Technology, Henan, China, 473004
}

Keywords: Applied person; landscape design major; teaching content

Abstract: Landscape design is an important component of education system of art majors in colleges and universities. Especially under the driving role of the development of landscape industry, landscape design majors win the favor of college students with their bright development prospects. With the further advancement and implementation of the institutional reform of education, the course content of landscape design specialty began to present new contents and features. In this context, how to build a new professional teaching system, deepen course teaching reform, highlight the training features of "applied talents", strengthen students' professional application ability, and further improve the core competitiveness of employment of students majoring in landscape design has become a key topic faced by relevant education workers.

\section{Introduction}

After entering the 21st century, the market economy has been developing vigorously, and the society has a large number of demands for applied talents, which also makes the position of landscape design major in domestic colleges and universities increasingly prominent. On the basis of the existing teaching mode, landscape design major should not only strengthen the cultivation of students' innovative thinking, but also pay attention to the training of students' practical ability, so as to achieve the training of application-oriented, highly educated professionals who meet the needs of the industry. This has also led to a significant change in the teaching methods of higher education in China, with more emphasis on the training of regional and local economic talents as the main goal of teaching, and the establishment of a practical teaching system that is compatible with the application-oriented educational goals. Therefore, the running mode and system of local universities have also undergone an earthshaking transformation, and the functional transformation is mainly to export a large number of high-level professional talents to the society.

As a landscape design major is different from other disciplines, it is a subject with comprehensive knowledge structure and strong multi-discipline. For the landscape design major education, it is necessary to have a diversified teaching method as a support. For the current teaching of this major, it should be urgently needed to establish a practical teaching system, strengthen practical teaching links and strengthen practical teaching, so as to cultivate applied talents and achieve the goal of serving local and regional economy. The current exploration of practical teaching methods has become an urgent problem to be solved ${ }^{[1]}$. 


\section{Teaching Ideas of Landscape Design with the Target of Applied Talents Training}

With the advent of knowledge-based economy, especially with the deepening development of economic globalization, colleges and universities should not only cultivate and develop students' professional design ability, but also further develop students' modern professional quality and professional skills practical application ability. It is obvious that the current teaching objectives and teaching ideas of landscape design major in colleges and universities have been gradually out of line with the times. If it is not improved and adjusted in time, it will seriously affect the role and status of this course in improving students' employment competitiveness. Therefore, in view of the current education development the new situation, work in the landscape design specialty teaching first-line teachers, should from the time development perspective, based on the current development needs, students' employment from the perspectives of teaching methods, teaching object, carries on the discussion, to strengthen the cultivation of student's professional accomplishment and professional application ability, let the students to in-depth knowledge in the learning activities ${ }^{[2]}$.

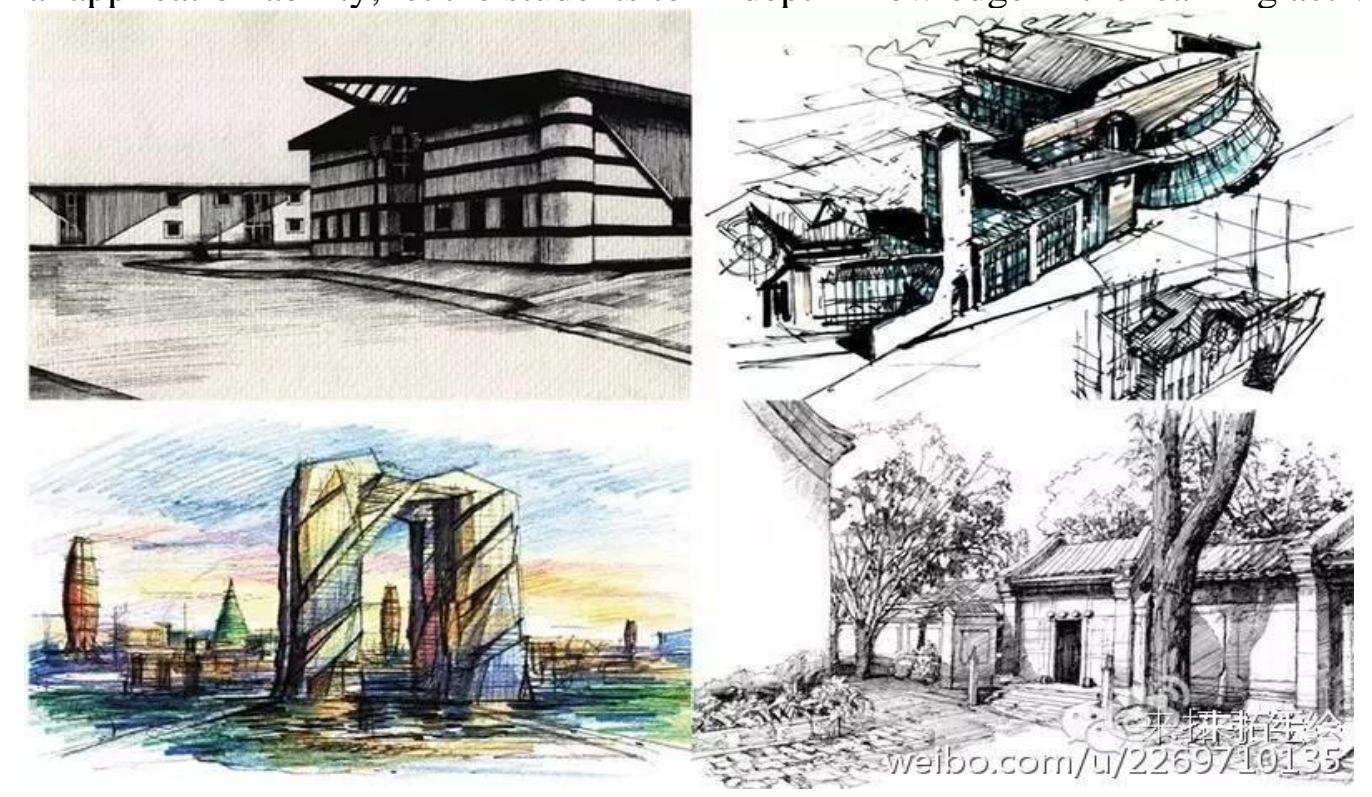

Figure 1: College student landscape design hand-painted works

\section{Analysis of Landscape Design Teaching Content Based on Application Talent Cultivation}

Landscape design class teaching showed obvious particularity, the theory of knowledge are relatively widely, and the practical ability and practice ability of students showed a higher requirements. so in the process of selecting the teaching content, teacher to students in both theoretical knowledge and at the same time more should strengthen and customer communication skills ability, strengthen the cultivation of landscape renderings hand-painted foundation of basic skills and strengthening the field survey of ability training, to ensure students' overall learning effect, for the applied talents training goal of eventually provide corresponding guarantee.

\subsection{Strengthen communication skills with customers}

In the new era, teachers in charge of professional teaching work should be separated from the traditional teaching concepts according to the requirements of the guiding documents for the development of innovative education, introduce employment issues into classroom teaching, help students establish employment goals, and let students learn with their goals. By opening a course of 
communication with customers, we can combine the knowledge we have learned with the reality of the company and strengthen the application of knowledge. Of course, based on the future employment development direction of college students, teachers also need to combine the professional characteristics of students to construct a new teaching model that caters to social development, individual needs and social needs, in order to gradually achieve the purpose of strengthening students' professional knowledge. Through the communication skills in the course, we can communicate with customers to better understand the needs of customers. Teachers also need to create roles in the classroom, so that students can truly experience the communication and interaction with customers in the role scenarios ${ }^{[3]}$.

\subsection{Strengthening the cultivation of hand-painted landscape renderings}

In order to achieve the training goal of applied talents, it is necessary to enhance the practicality and expandability of the curriculum teaching, and develop students' fast hand-painting skills on the spot. The on-campus training room is a place for students to carry out simulation practice teaching. It is the basic guarantee for cultivating applied talents in landscape design. It provides convenient conditions for practical teaching of landscape design students.

In order to highlight the characteristics of colleges and universities, students will be trained as a landscape design professional application talents who are favored by employers and meet the needs of social development. Breaking the dependence of students on the computer renderings in the traditional teaching mode, the teacher leads the students to go to the major scenic spots to carry out hand-painted landscape sketching, returning the classroom to nature, in order to improve the quality of practical teaching. Increase the original course architecture sketch, design the performance of the course hours. In addition, teachers should also pay attention to the role of hand-painted landscape effect drawings in expressing design ideas and concepts, strengthen the cultivation of students' foundation, inspire students' spatial imagination and innovative consciousness, and enable students to achieve rapid hand-painted effect pictures through intensive training ${ }^{[4]}$.

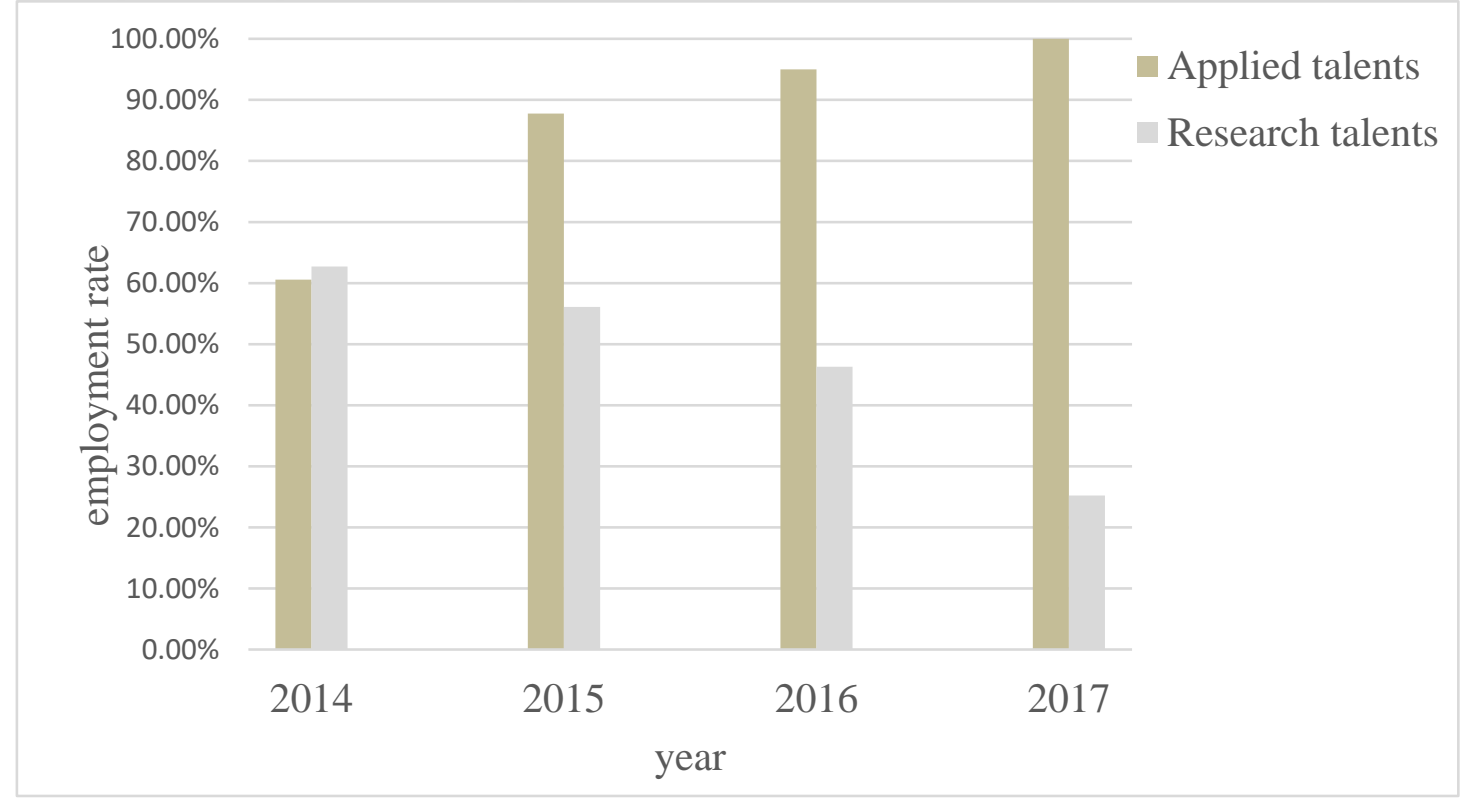

Figure 2: Statistics of employment rate of landscape design students in recent years

\subsection{Strengthen the cultivation of field survey capability}

The process of cultivating students' professional skills is not a one-time process, but it requires a 
lot of practice baptisms to gradually develop the qualities of individual expression and personal design style. However, to enrich your design experience, it is not enough to rely solely on the practical opportunities offered in the classroom. This requires strengthening students' professional skills and practical exercises to help students transfer the knowledge they have learned in the classroom to real life and apply them to the practice of solving practical problems.

In the middle of the course, they will organize them to the local landscape area for a field survey in a week or so, so that students can understand the basic knowledge of the landscape design course, especially the characteristics of the landscape area. In this way, students can get a preliminary understanding of their future work tasks and the knowledge they need to learn before they come into contact with their professional knowledge. In addition, the school can also set up corresponding comprehensive training courses for the actual needs of the course, arrange students to carry out appropriate landscape field survey internships, comprehensively apply the basic knowledge of landscape design and design techniques, and carry out targeted survey activities in combination with actual internship projects ${ }^{[5]}$.

\section{Conclusions}

To sum up, it is not only the development need of education reform in colleges and universities, but also the inevitable behavior of conforming to the trend of development in the era of knowledge economy to realize innovative teaching of landscape design courses to improve students' professional skills and professional practical application ability. Therefore, relevant teachers should build a new teaching system, reform traditional teaching methods, gather strength to develop and cultivate new applied talents of art design based on the development needs of students' comprehensive ability and the goal of cultivating application-oriented talents in the practice of course content teaching.

\section{References}

[1] Tan Jie. Landscape Education and Applied Landscape Talent Cultivation from Ecological Civilization Issues [J]. Shandong Social Sciences, 2015(S2).

[2] Yu Min, Zhang Yahui. Research on the Strategy of Professional Talents Cultivation of Landscape Design under the Concept of "Excellence" + "CDIO" [J]. Jiangxi Building Materials, 2016(4): 290-290.

[3] Li Guorui. Discussion on Teaching Reform of Landscape Design Courses [J]. Beijing Agriculture, 2015(5).

[4] Jia Zhongfeng, Li Chuangang. Reflections on the Practical Teaching Mode of Landscape Design Course[J]. Education and Occupation, 2012(24):168-169.

[5] Zhou Xingwen, Yang Xiangchun, Wu Min, et al. Reform of the Garden Course System of Yulin Teachers College with the Cultivation of Applied Talents[J]. Education and Teaching Forum, 2016(49):72-73. 